\title{
Søvnmangel øker kaloriinntaket
}

\section{Søvnmangel gir økt forbrenning, men energiinntaket øker mer enn forbrenningen. Dette funnet kan forklare assosiasjonen mellom søvnmangel og fedme.}

I et nøye kontrollert laboratorieforsøk har forskere kartlagt mulige mekanismer bak assosiasjonen mellom søvnmangel og fedme. Etter en tilpasningsperiode på tre døgn i laboratoriet, med anledning til å sove inntil ni timer om natten, fikk halvparten av deltakerne begrenset søvnvarigheten til fem timer

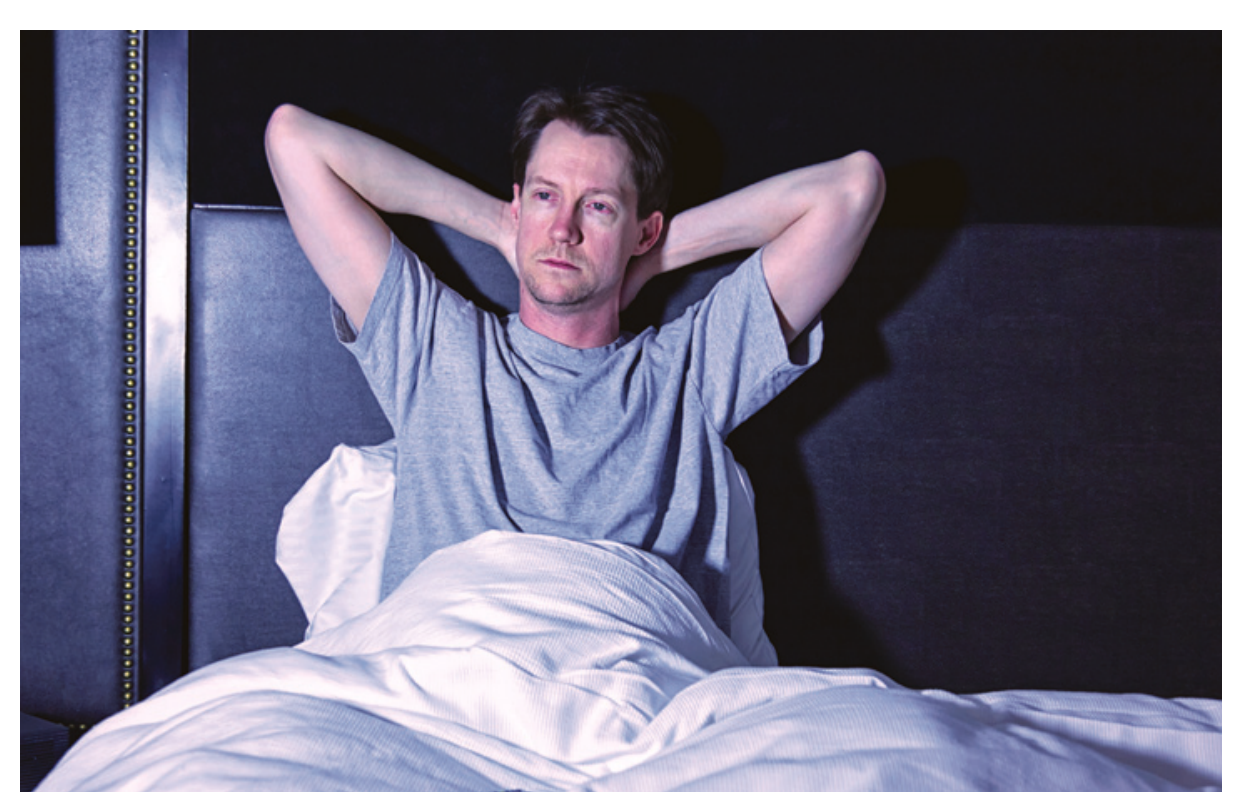

Illustrasjonsfoto Istockphoto per natt i fem døgn, mens resten fortsatte med inntil ni timers søvn (1). Deretter skiftet gruppene søvnregime.

Søvnmangel økte energiforbruket, men kaloriinntaket økte enda mer, til tross for at blodkonsentrasjonene av leptin, ghrelin og peptid YY snarere burde ha ført til lavere

matinntak. Andre mediatorer som kan ha stimulert appetitten, som tyroksin, CCK, GLP 1 og oreksin/hypokretin, ble ikke analysert. Det ekstra matinntaket besto først og fremst av fritt tilgjengelig snacks.

- Kortere søvnlengde øker energiforbruket, men i denne undersøkelsen øker altså energiinntaket mer enn forbruket, sier professor emeritus Per A. Brodal, Institutt for medisinske basalfag, Universitetet i Oslo.

- Økningen i kaloriinntaket vil medføre betydelig vektøkning over tid. Studien kan ikke si noe om årsaken til denne økningen, men forfatterne mener at psykologiske mekanismer mest sannsynlig overstyrer den hormonelle reguleringen. Min gjetning er at fenomenet kanskje kan forstås ved å se på opplevelse av tretthet som signal om virkelig eller truende energimangel. I menneskets utvikling, med knapphet på energi som hovedregel, ville adekvat atferd ved tretthet være å redusere energikrevende aktiviteter. Men med overflod av lett tilgjengelig høyenergimat vil rimeligvis den mest meningsfulle atferden være å spise, selv om dette medfører overstyring av de fysiologiske feedbackmekanismene, sier Brodal.

\section{Haakon B. Benestad}

h.b.benestad@medisin.uio.no

Universitetet i Oslo

\section{Litteratur}

1. Markwald RR, Melanson EL, Smith MR et al. Impact of insufficient sleep on total daily energy expenditure, food intake, and weight gain. Proc Natl Acad Sci U S A 2013; 110: 5695-700.

\section{Kreft med ukjent utgangspunkt er blitt mindre vanlig}

\section{Kreft med ukjent utgangspunkt ble endelig kreftdiagnose hos en av 20 kreftpasienter for 20 år siden. Nå får cirka en av 100 denne diagnosen.}

Noen ganger kan man, til tross for grundig utredning, ikke konkludere med organspesifikt utgangspunkt etter at en kreftdiagnose er stilt, og diagnosen blir Cancer origo incerta - kreft med ukjent utgangspunkt. Dette medfører en dårligere prognose fordi behandlingen må gis på bakgrunn av antakelser om opphav.

Vi har gjennomgått forekomst og beregnet overlevelse ved denne diagnosen i Norge fra 1971 til 2010 basert på tall fra Kreftregisteret, totalt 23004 tilfeller (1). I første halv- del av perioden økte andelen uten organspesifikk diagnose gradvis. Toppunktet ble nådd rundt 1990, da 4,8\% av kvinnelige kreftpasienter og 4,3\% av mannlige kreftpasienter fikk denne diagnosen. Tilsvarende tall i 2010 var $1,7 \%$ og 1,2\%. Ettårsoverlevelsen ved diagnosen kreft med ukjent utgangspunkt har ligget rundt $10 \%$ inntil den siste femårsperioden, der det har vært en markert stigning til $18,3 \%$ for kvinner og $19,4 \%$ for menn.

Hovedårsaken til nedgangen er trolig en gradvis bedret diagnostikk, med økt bruk av CT, MR og PET-CT, samt endoskopiske teknikker. Bedre patologisk diagnostikk, ikke minst grunnet $ø \mathrm{kt}$ bruk av immunhistokjemiske markører, har også bidratt til en større andel konklusive organrelaterte diagnoser.
Bedret kreftbehandling generelt har kommet denne diagnosegruppen til gode, selv om prognosen fortsatt er dyster. I tillegg er det mulig at andelen av diagnoser med spesielt aggressive forløp, som lungekreft og bukspyttkjertelkreft, nå i mindre grad er representert $\mathrm{i}$ entiteten Kreft med ukjent utgangspunkt, pga. bedret diagnostikk.

\section{Odd Terje Brustugun \\ otr@radiumhospitalet.no \\ Oslo universitetssykehus}

\section{Litteratur}

1. Brustugun OT, Helland $\AA$. Rapid reduction in the incidence of cancer of unknown primary. A population-based study. Acta Oncol 2013; e-publisert 4.4.2013. 